\section{A UNIQUE OBSTETRICAL EVENT.}

\section{To the Editor of THE LANCET.}

SrR,-The interesting paragraph in the Vienna letter in THE LANCET of June 11th headed "A Jnique Obstetrical Event "reminds me of Dr. Whaley's case, ${ }^{1}$ althougb this was a case of a monocephalic iliadelphic monster and not a case of twin-sisters. A woman, with one head and one body, was donble from the waist downwards; she had two navels, two external genital organs, and four legs ; she could walk on the two external legs only, the two internal ones being too small and too short. She married and became pregnant in her left side. Owing to some dangerous symptoms, and fearing the pelvis would be too contracted, Dr. Whaley had a consultation with Dr. Haden and Dr. Aldridge. They decided to induce premature labour at three and a half months. The patient recovered perfectly.

I am, Sir, yours faithfully,

Geneva, June 15th, 1910 A. CoRdes, M.D. Paris.

\section{INTENSE PIRQUET'S REACTION WITH ULCERATION CURED BY HORSE SERUM.}

To the Editor of THE LANCET.

SIR, - This case became available just too late to be added to my paper which you published in THE LANCET of June $25 \mathrm{th}$ on the treatment of ulcers by horse serum. It illustrates not only the arrest of auto-cytolysis by the antitryptic power of normal horse serum, but also a complication of Pirquet's reaction of which $I$ have seen no record.

The patient was a well-nourished child, aged $2 \frac{1}{2}$ years, who for four weeks had had slight fever and a doughy abdomen, probably due to tuberculous peritonitis. The cuti-reaction was tested with undiluted old tuberculin. as my house physician, Miss S. E Buyers, who has had considerable experience of this test, found that negative results were unduly frequent with the 25 per cent. dilution. The response was very violent, though with no indication of septic invasion. In a week an ulcer was visible which on the fourteenth day had raised edges and a diameter of $18 \mathrm{~mm}$. The base was polished and showed no sign of granulation or attempt at healing. It seemed, in fact, a sluggish, spreading cytolytic ulcer of the forearm of unusual type. On the sixteenth day horse serum was applied locally on gauze. On the eighteenth day granulations were visible, and on the twentyfirst day there was an ingrowth of healthy skin from the edges, and healing became well established.

Incidentally I may add that we have tried the Moro's tuberculin ointment test somewhat extensively in the Children's Hospital here and have abandoned it owing to the rarity of positive reactions as controlled by Pirquet's test. I am, Sir, yours faithfully,

Hull, June 25th, 1910

FranK C. Eve.

Atropine in the Treathent of Tetanus. - We published an annotation on this subject in THE LANCET of May 21st, 1910 , p. 1430 . We said we had received a letter giving an account of two cases of tetanus from Dr. R. F. Secoresto of Barbados. We should have said "from Dr. R. F. Licorish, of Barbados." Our correspondent's signature was not at all legible, and the local list in the Medical Directory gave no clue. We much regret the error, but are relieved to learn from Dr. Licorish's humorous letter of expostulation that we are by no means the only persons who, failing to decipher his signature, "have played havoc with the name again and again."

1 American Journal of Obstetrics, 1888, p. 1265.

North-East London Post-Graduate College. -A Vacation Course will be held in connexion with this College from Sept. 12th to 23rd inclusive. The course will include demonstrations on recent clinical methods, demonstrations of groups of selected clinical cases, clinical lectures and lantern demonstrations, and clinical consultations. The inclusive fee will be 2 guineas. Full particulars may be had from the Dean at the Prince of Wales's General Hospital, N.
THE HOUSING PROBLEM AT LIVERPOOL.

(From our Speciat Sanitary Commissioner.)

Liverpool, June, 1910.

LIVERPOOL, as already explained, ${ }^{1}$ has laid out broad thoroughfares and planned residential quarters in the midst of uninhabited fields, and this was done long before the Town Planning Act was promulgated. Such promptitude was the result of a reaction against the abominable state of things which had been allowed to grow up in the city without any check or interference. With the development of the cotton manufactories in Lancashire, Liverpool, as the port where the cotton from America was landed, grew in importance. The need for cheap manual labour in the docks increased in due proportion, and then narrow streets with courts and alleys, cellar dwellings, and baek-to-back houses were built as near as possible to the water's edge for the use of all these poorly paid casual labourers and dockers. To this must be added the fact that some 80,000 Irish who fled from the potato famine in 1845 landed and settled in Liverpool en bloc, accounting for a very large Irish colong which still remains in the city. Of course, when they arrived, penniless and starving, from their famine-stricken country, they had to accept the worst paid work, and indeed they did not possess the technical knowledge necessary to earn anything above starvation wages. All this contributed to create the slums for which Liverpool became unfortunately celebrated. These were the classic haunts of typhus fever; the home of drunkenness, immorality, and crime; and the cause of an appallingly high death-rate. Every backyard in the districts inhabited by the labouring class was built upon, as well as every green space. Nothing was done practically to control these building operations. In 1846, the year following the Irish invasion, a law was enacted with the following title: "An Act for the Promotion of the Health of the Inhabitants of the Borough of Liverpool, and the Better Regulation of Buildings in the Said Borough." Beyond the closing of a few cellar dwellings the Act effected very little real improvement, and the same may be said of a similar Act passed four years earlier. The first measure of genuine use was passed in 1854, under which it became an illegal act to construct any more houses of the worst type. But the speculators in slum property had foreseen this legislation and had erected thousands of the vilest court dwellings just a zear or two before such structures were pronounced to be illegal. In the first instance nothing could be done by which existing insanitary property might be removed; the new legislation only sought to prevent the increase of existing evils. Ten years had to elapse before an effective law dealing with the past could be added to that which dealt with the future. This is a strange commentary on the legislation of a practical people. Here were slums with a death-rate of 60 per 1000 per annum. They were veritable hot-beds of zymotic disease, especially of typhus fever. These slums constituted centres of physical and moral contamination for all, and not only for the numerous seafaring population attracted to the port. Yet, instead of at once taking in hand the existing mischief, the law was directed only against evils which might possibly come into being at some future day. We are only told by the law of 1854 that in future labourers' dwellings must be built on a better plan.

$$
\text { How the Slums nere First Attacked. }
$$

After this pronouncement ten years elapse, each with its swollen death-rate dae to the typhus-stricken slums, and at last a law is enacted which does deal, not with grievances that may arise, but with the monstrous conditions actually prevailing. The Liverpool Sanitary Amendment Act of 1864 gave the corporation of Liverpool extensive powers for the acquisition of insanitary property, and was a very advanced piece of legislation, at least for those days. Much of the re-housing of Liverpool bas been carried out under this Act, and it has proved a most useful measure. The means of procedure established by this law were as follows. The Act specifies certain sort of houses which the medical officer of health, if he thought proper, might condemn as unfit for human habitation. In that case what is called a "presentment" was made to the grand jury at quarter 